\title{
Edukasi Pemahaman Covid-19 pada Pemudik dengan Status ODP (Orang Dalam Pengawasan) Di Desa Sumber Agung Kabupaten OKU Timur
}

\author{
Arini Rosa Sinensis ${ }^{1}$, Thoha Firdaus ${ }^{2}$, Ari Khusuma ${ }^{3}$ \\ ${ }^{1,2}$ Sekolah Tinggi Keguruan dan Ilmu Pendidikan Nurul Huda \\ OKU Timur, Indonesia \\ ${ }^{3}$ Politeknik Kesehatan Kementerian Kesehatan Mataram, Indonesia \\ arini@stkipnurulhuda.ac.id*
}

\begin{abstract}
Abstrak
Covid-19 merupakan virus yang telah menginfeksi manusia hampir diseluruh dunia pada awal tahun 2020 . Virus ini telah masuk di Indonesia pada awal maret 2020 dan penyebarannya begitu cepat. Di Indonesia masa pandemik ini bertepatan dengan hari raya idul fitri $1441 \mathrm{H}$ yang jatuh pada tanggal 23 mei 2020 oleh karena itu, pemerintah menerapkan Pembatasan sosial berskala besar (PSBB) karena dipandang efektif dalam menekan atau membatasi pergerakan orang antar wilayah dan menghentikan penyebaran covid-19 ke berbagai wilayah Indonesia. Pengabdian kepada masyarakat ini bertujuan untuk memberikan edukasi kepada masyarakat khususnya warga yang berstatus ODP (Orang dalam Pengawasan) tentang bahayanya virus Covid-19, menjelaskan pencegahannya dan membiasakan pola hidup bersih dan sehat (PHBS). Kegiatan pengabdian ini dilaksanakan di desa sumber agung kabupaten OKU Timur Sumsel. Sasaran pengabdian ini adalah warga OKU Timur yang mudik dari daerah berdampak Covid-19. Warga mudik tersebut telah ditandai dengan status ODP. Edukasi ini memberikan dampak terhadap bertambahnya wawasan dan pengetahuan masyarakat tentang bahayanya covid-19, menerapkan pola hidup bersih dan sehat serta membiasakan konsumsi madu untuk meningkatkan imunitas tubuh. Kegiatan ini mendapatkan respon positif oleh perangkat desa dan masyarakat sebagai upaya dalam pencegahan penyebaran Covid-19 di daerah.
\end{abstract}

Kata Kunci: Covid-19, ODP, Edukasi

\section{Abstract}

Covid-19 is a virus that has infected humans almost all over the world in early 2020. This virus has entered Indonesia in early March 2020 and is spreading so fast. In Indonesia, this pandemic period coincides with Eid al-Fitr $1441 \mathrm{H}$ which falls on May 23, 2020, therefore, the government implements large-scale social restrictions (PSBB) because it is considered effective in suppressing or limiting the movement of people between regions and stopping the spread of Covid-19. to various parts of Indonesia. This community service aims to provide education to the community, especially residents with ODP status (people under surveillance) about the dangers of the Covid-19 virus, explain its prevention and get used to a clean and healthy lifestyle (PHBS). This service activity was carried out in Sumber Agung village, East OKU district, South Sumatra. The target of this service is East OKU residents who go home from the area affected by Covid-19. The homecoming residents have been marked with ODP status. This education has an impact on 
increasing public insight and knowledge about the dangers of Covid-19, implementing a clean and healthy lifestyle and getting used to consuming honey to increase body immunity. This activity received a positive response by village officials and the community as an effort to prevent the spread of Covid-19 in the regions.

Keyword: Covid-19, ODP, Education

\section{PENDAHULUAN}

Awal tahun 2020 masyarakat seluruh dunia digemparkan dengan adanya virus corona yang berasal dari kota wuhan china. Virus ini telah menginfeksi 5,9 juta jiwa pada tanggal 29 Mei 2020 yang dilansir dari kompas.com. Di Indonesia pemerintah telah mengeluarkan pernyataan resmi tentang darurat bencana Covid-19 terhitung pada tanggal 29 februari 2020 hingga mei 2020. Sejak per tanggal 5 juni sudah tercatat sebanyak 29,521 orang yang dinyatakan positif Covid-19 (Kependudukan.lipi.go.id). Selain berdampak pada aspek kesehatan, bencana Covid-19 ini juga sangat berdampak pada mobilitas dan perekonomian yang mengalami perubahan secara signifikan. Dampak dari kondisi ini pemerintah berupaya untuk mengeluarkan kebijakan untuk membatasi mobilitas orang dengan aturan Pembatasan sosial berskala besar (PSBB). PSBB ini dilakukan diberbagai daerah cara ini dipandang efektif dalam menekan atau membatasi pergerakan orang antar wilayah dan menghentikan penyebaran covid-19 ke berbagai wilayah Indonesia.

Di Indonesia masa pandemik ini bertepatan dengan hari raya idul fitri $1441 \mathrm{H}$ yang jatuh pada tanggal 23 mei 2020. Masyarakat Indonesia memiliki budaya mudik atau pulang kampung bagi para perantau. Soebyakto (2011) menjelaskan bahwa mudik lebaran adalah sebuah kebiasaan yang dilakukan oleh umat islam yang berada diperantauan atau tinggal jauh dari kampung halaman untuk pulang ke asal kampung halamannya. Kebiasaan mudik lebaran dilakukan pada satu minggu sebelum lebaran hingga seminggu sesudah hari raya tersebut. Aktivitas mudik inilah yang menjadi kekhawatiran pemerintah sehingga muncul peraturan pembatasan mobilitas masyarakat pemudik.

Pembatasan mobilitas mengakibatkan sulitnya para perantau untuk melakukan mudik atau pulang kampung ke daerah asal untuk merayakan hari raya idul fitri. Himbauan dan sosialiasi dari pemerintah untuk "Sayangi Keluarga di Kampung, Lebih Baik Silaturahmi Via Digital' yang tertulis pada laman situs https://covid19.go.id/. Sosialisasi tersebut diharapkan menggugah kesadaran masyarakat untuk menunda mudik. Pada kenyataannya tradisi mudik atau pulang ke kampung halaman masih dilakukan oleh banyak perantau, himbauan dari pemerintah hanya angin lalu saja. Tidak hanya larangan mudik, pemerintah juga berupaya untuk menghambat terjadinya arus balik. Himbauan ini dituangkan pada surat edaran Gugus Tugas Percepatan Penangan COVID-19 Nomor 5 tahun 2020 tentang perpanjangan masa berlaku pembatasan mobilitas orang dalam rangka percepatan penanganan dan penanggulangan penyebaran Covid-19 hingga 7 juni 2020.

Banyak masyarakat di desa Sumber Agung Kabupaten OKU Timur Provinsi Sumatera Selatan yang bekerja (merantau) dan sekolah di luar daerah yaitu Palembang, lampung, Jakarta, Jawa Barat, Jawa Tengah dan Jawa Timur (Data Desa Sumber Agung, 2020). Aktivitas mudik lebaran di desa sumber agung selalu dilakukan tiap tahun biasanya 10 Hari sebelum Idul Fitri. Pandemi Covid-19 tidak menghalangi pemudik untuk pulang kampung halaman. Berdasarkan wawancara kepada para pemudik didapatkan informasi tentang alasan mengapa mudik: 1) Di daerah rantau ada peraturan PSBB Ketat, 2) Tidak mendapatkan penghasilan dan 3) Takut dengan Covid-19, 4) Ingin kumpul keluarga saat Lebaran. Alasan tersebut yang mendasari para pemudik untuk pulang kampung.

Sejak adanya pandemi Covid-19 di desa Sumber Agung telah melakukan upaya dalam pencegahan dan penanggulangan penyebaran virus, diantaranya mewajibkan setiap rumah untuk menyediakan tempat 
cuci tangan dan sabun serta membagikan masker kepada warga. Akan tetapi, belum adanya edukasi langsung dari Pemerintahan desa Sumber Agung yang mengajak warganya untuk jaga jarak dan isolasi mandiri bagi warga yang datang dari luar kota. Selain itu, mobilitas dan segala aktivitas warga seperti di pasar, hajatan dan kerumunan lainnya masih tetap dilaksanakan. Hal ini disebabkan karena kurangnya pengetahuan masyarakat akan bahayanya covid-19 dan desa membutuhkan sumber daya manusia untuk membantu mengedukasi masyarakat.

Berdasarkan uraian tentang masalah yang dihadapi mitra maka sebagai salah satu perguruan tinggi STKIP NH Sukaraja yang berada ditengah masyarakat yang masih awam terkait bahaya Covid-19 perlu melakukan edukasi sebagai upaya mendukung program pemerintah dalam penanganan dan pencegahan penularan Covid-19 dalam kegiatan pengabdian kepada masyarakat. Edukasi kepada masyarakat yang dilakukan dalam hal menerapkan pola hidup bersih, jaga jarak, menjaga imunitas tubuh, pakai masker dan isolasi mandiri bagi warga dari luar kota terdampak.. Kegiatan edukasi ini diharapkan akan memberikan pengetahuan baru kepada masyarakat awam khususnya yang ada di pedesaan agar lebih berhati-hati dan patuh terhadap aturan pemerintah. Upaya ini juga diharapkan meningkatkan kolaborasi antara perangkat desa, tenaga kesehatan dan masyarakat untuk saling memberikan dukungan, gotong royong dalam rangka pencegahan Covid-19 di daerah.

\section{METODE}

Kegiatan pengabdian kepada masyarakat dilaksanakan selama 2 hari di Desa Sumber Agung Kecamatan Buay Madang, Kabupaten OKU Timur provinsi sumatera selatan. Pada hari pertama kegiatan di awali dengan persiapan, yaitu melakukan izin dan koordinasi dengan kepala desa dan meminta data seluruh ODP (Orang dalam Pengawasan) yaitu orang yang mudik dari kota atau provinsi terdampak covid19. Terdata 7 ODP di desa sumber Agung yang berhasil mudik dari Provinsi Lampung, Kota Palembang, Provinsi Jawa Timur dan Jakarta. Kegiatan edukasi ini juga didampingi oleh bidan dan perangkat desa sumber agung. Aktivitas kegiatan koordinasi ditampilkan pada Gambar 1 dan 2.

Gambar 1. Koordinasi dan diskusi dengan perangkat desa

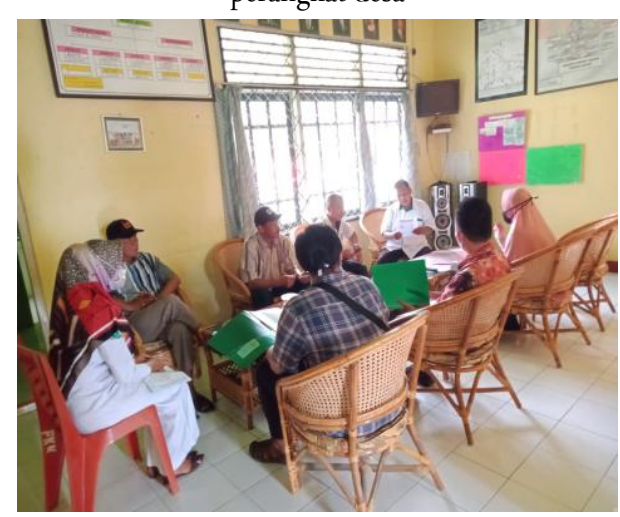

Gambar 2. Koordinasi dengan Perangkat dan

Bidan Desa

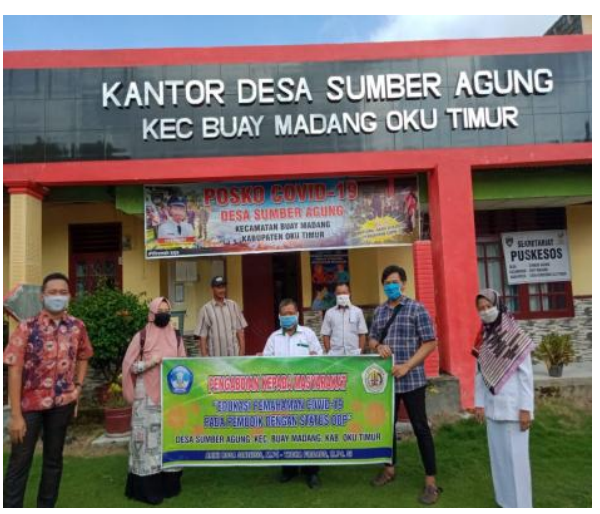

Hari kedua adalah kegiatan inti yaitu melakukan kunjungan ke rumah warga yang berstatus ODP. Pada kegiatan ini edukasi dilakukan dengan memberikan sebuah himbauan, membagikan poster waspada Covid-19 dan pemberian madu untuk menjaga imunitas tubuh. 


\section{HASIL DAN PEMBAHASAN}

Edukasi dilakukan pada orang yang berstatus ODP merupakan bentuk kepedulian warga dalam upaya pencegahan Covid-19 di pelosok daerah khususnya sumber Agung. Maraknya warga yang mudik karena covid-19 dan menjelang lebaran membuat sebagian warga menjadi takut. Beberapa edukasi yang dilakukan diantaranya adalah:

\section{1) Himbauan}

Perangkat desa memberikan himbauan kepada warga ODP tersebut agar melakukan isolasi mandiri selama 14 hari dan meminta warga melapor ke kantor desa jika telah menyelesaikan isolasi. Selain itu, memberikan himbauan agar lapor ke kantor desa secepatnya jika melihat ada warga yang mudik dari daerah terdampak covid-19. Bidan desa juga memberikan penjelasan tentang bahayanya covid-19 meliputi; penyebaran, gejala yang dialami yang berdampak pada resiko yang menimbulkan kematian. Melalui penjelasan dari tenaga kesehatan yaitu bidan desa diharapkan masyarakat atau warga yang berstatus ODP mendapat pengetahuan lebih datail dan jelas.

Gambar 3. Kunjungan kerumah warga dan megedukasi warga berstatus ODP

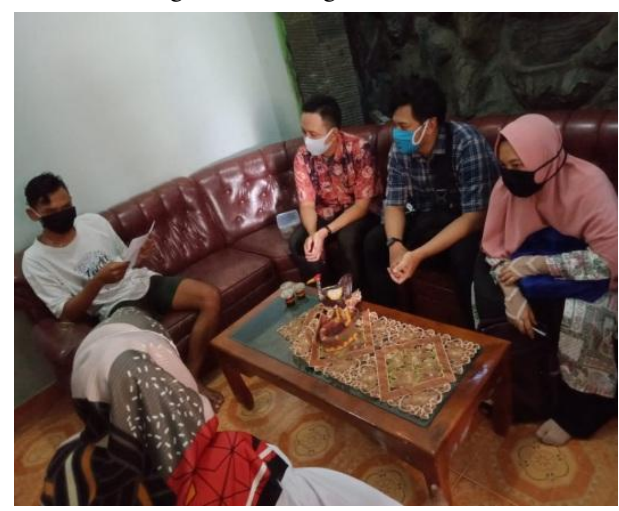

Gambar 4. Bidan Desa dan Perangkat desa menghimbau warga berstatus ODP

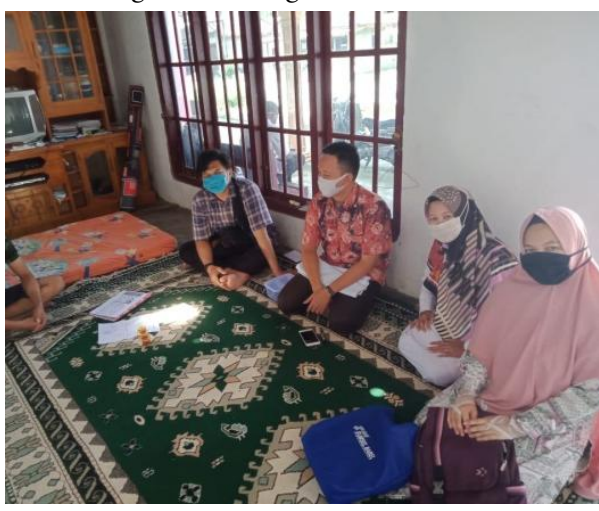

\section{2) Membagikan Poster}

Poster dibagikan kepada warga yang berstatus ODP dengan tujuan agar dapat dipahami bagaimana cara isolasi mandiri yang baik, menaati protokol kesehatan, menggunakan masker selama berpergian maupun ditempat kerumunan. Poster yang diberikan ditampilkan pada gambar berikut:

Gambar 5. Poster Edukasi yang diberikan untuk warga berstatus ODP
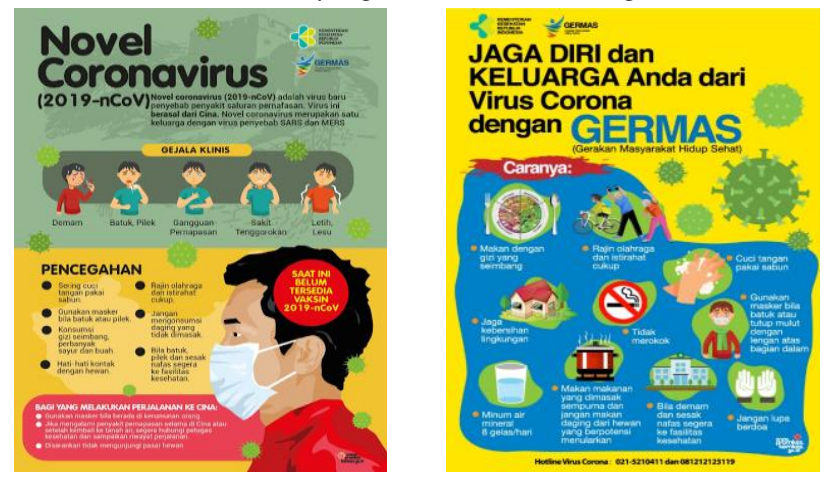
Memberikan poster Gerakan Masyarakat Hidup sehat juga dilakukan sebagai wujud pencegahan virus covid-19. Media poster yang disajikan dalam bentuk gambar dengan tampilan yang merarik akan mudah diingat (Zukmadini et al., 2020). Hasil penelitian (Sumartono \& Astuti, 2018) menunjukkan bahwa penggunaan media poster sangat efektif jika digunakan sebagai media komunikasi kesehatan. Hal ini karena tampilan yang menarik, didesain dengan perpaduan warna dan isi pesan bermanfaat bagi pembaca. Sehingga pesan yang ada di dalam poster mudah diingat bahkan diaplikasikan.

Pengetahuan tentang perilaku hidup sehat melalui edukasi pengetahuan tentang kesehatan dan pola hidup bersih dan sehat (PHBS) (Proverawati, Atikah; Rahmawati, 2020; Sulaeman \& Supriadi, 2020) adalah poin utama agar terhindar dari penularan/transmisi virus corona-19. Sebenarnya program PHBS di indonesia telah di gaungkan sejak lama oleh kemenkes dan dituangkan dalam pedoman PHBS (Kemenkes, 2011) dan terbagi menjadi 5 tatanan yaitu rumah tangga, institusi pendidikan, tempat kerja, tempat umum dan fasilitas kesehatan. Pada masa pandemi covid kegiatan PHBS salah satunya adalah mencuci tangan minimal 60 detik. Mengutip dari https://covid19.kemkes.go.id/ terdapat lima waktu penting untuk mencuci tangan. 1) sebelum makan, 2) setelah buang air besar (BAB), 3) sebelum menyentuh makanan, 4) sebelum menyusui dan 5)sebelum melakukan aktifitas.

Warga dengan satus ODP juga diberi penjelasan tentang pentingnya penggunaan masker. Penggunaan masker merupakan bagian dari langkah pencegahan penyebaran penyakit dan virus termasuk COVID-19. Masker dapat digunakan oleh individu karena efektif untuk melindungi orang yang sehat dari penyebaran penyakit/virus (jika masker dipakai oleh orang yang sakit) begitu juga sebaliknya masker dapat dipakai untuk untuk melindungi diri sendiri saat kontak dengan orang yang terinfeksi. Masker dipandang efektif jika digunakan dengan baik oleh orang yang terinfeksi untuk pencegahan dan penyebaran penyakit (WHO, 2020).

Edukasi selanjutnya yaitu memberikan pengetahuan tentang Pembatasan interaksi fisik atau physical distancing seperti yang telah dijelaskan di pedoman penanganan cepat medis dan kesehatan masyarakat covid-19 di indonesia oleh (KEMENKES, 2020) melipuit: 1) Dilarang berdekatan, berkumpul dan berkerumun di keramaian atau tempat umum, jika terpaksa maka gunakan masker. 2) Tidak menyelenggarakan kegiatan/pertemuan yang melibatkan banyak orang/perkumpulan masa, 3) Hindari perjalanan baik ke luar kota maupun ke luar negeri, 4) Hindari mengunjungi tempat wisata atau hiburan. 5) Kurangi atau tunda dahulu mengunjungi kerabat/teman/saudara dan sebaliknya. 6) Mengurangi aktivitas belanja dan pergi berbelanja. Jika terpaksa, usahakan tidak pada jam ramai. 7) Menerapkan kerja dan belajar dari rumah Work From Home (WFH), 8) Jaga jarak minimal 1 meter, 9) Hindari wisata bermain untuk anak, aktivitas bermain anak sebaiknya dirumah. 10) dan aktivitas ibadah dilakukan di rumah. Ketiga PHBS seperti mencuci tangan, menggunakan masker dan menerapkan physical distancing menjadi bagian utama dari kegiatan edukasi ini. Berikut ini adalah aktivitas Edukasi pada program pengabdian kepada masyarakat yang ditampilkan pada Gambar 6.

\section{3) Membagikan Madu}

Madu sampai saat ini dianggap berkhasiat untuk menjaga imunitas tubuh. Telah disarankan bahwa konsumsi madu dapat memberikan beberapa efek menguntungkan pada respon kekebalan manusia dan mekanisme yang terkait. (Cortés et al., 2011). Oleh karena itu, pemberian madu dilakukan untuk memberikan edukasi kepada masyarakat bahwa dengan mengkonsumsi madu diharapakan warga yang bertatus ODP dapat menjaga daya tahan tubuhnya. Madu sangat bergizi, memiliki kandungan mineral dan vitamin, belum lagi antioksidan yang menghancurkan radikal bebas dan menunda penuaan. Dengan mengkonsumsi madu maka akan membuat tubuh tetap sehat dan kuat. Madu adalah anti bakteri, antivirus 
dan anti jamur, dan semua khasiat ini membuatnya ideal untuk penyembuhan luka. Sistem kekebalan: Penggunaan madu dan bubuk kayu manis jika dikonsumsi setiap hari maka akan memperkuat sistem kekebalan dan melindungi tubuh dari serangan bakteri dan virus. Pada madu telah ditemukan oleh para ilmuan bahwa memiliki kandungan vitamin dan zat besi dalam jumlah banyak. Penggunaan madu secara konstan memperkuat sel darah putih untuk melawan penyakit bakteri dan virus (Kumar \& Bhowmik, 2010). Berikut ini kegiatan edukasi pemberian madu dan pengecekan suhu tubuh warga ODP oleh bidan desa sumber agung.

Gambar 6. Aktivitas Edukasi Covid-19 terhadap Warga ODP
Gambar 6. Aktivitas Edukasi Covid-19 terhadap Warga ODP

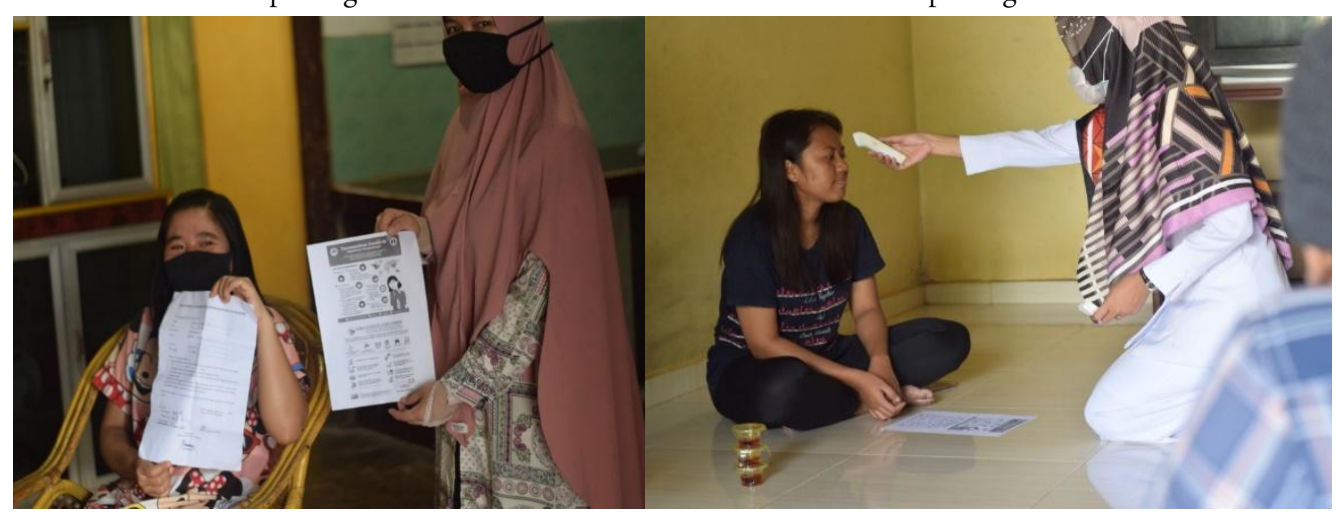

\section{KESIMPULAN}

Kesimpulan yang diperoleh dalam kegiatan pengabdian kepada masyarakat adalah masyarakat memberikan repson positif terhadap kegiatan edukasi yang dilakukan. Kegiatan edukasi ini juga mendukung program pemerintah dalam upaya pencegahan penyebaran covid-19 di daerah. Warga yang berstatus ODP mendapatkan pengetahuan baru dan penjelasan terkait pencegahan covid-19 dan pola hidup bersih dan sehat (PHBS).

\section{UCAPAN TERIMA KASIH}

Terima kasih kepada Kepala Desa Sumber Agung Kab. OKU Timur berserta perangkatnya. Atas partisipasinya dan kerjasamanya dalam kegiatan pengabdian edukasi covid.

\section{DAFTAR PUSTAKA}

Cortés, M. E., Vigil, P., \& Montenegro, G. (2011). The medicinal value of honey: a review on its benefits to human health, with a special focus on its effects on glycemic regulation. Ciencia e Investigación Agraria, 38(2), 303-317. https://doi.org/10.4067/s0718-16202011000200015

Kemkes, Covid-19. (2020). Begini Cara Mencuci Tangan Yang Benar. diakses pada 16 Juni 2020, dari https://covid19.kemkes.go.id/warta-infem/begini-cara-mencuci-tangan-yang-benar/\#.X7s7DGgzY2x.

Kemenkes. (2011). Peraturan Menteri Kesehatan Republik Indonesia. In Peraturan Menteri Kesehatan No. 2406 TAHUN 2011 tentang Pedoman Umum Penggunaan Antibiotik.

KEMENKES. (2020). Gugus tugas percepatan penanganan covid-19 1. Gugus Tugas Percepatan Penanganan Covid-19, 1-39.

Kependudukan LIPI. (2020). Susah mudik susah balik dampak pandemi covid-19. diakses 199 September 2020, dari https://kependudukan.lipi.go.id/id/berita/53-mencatatcovid19/962-sudah-mudik-susah- 
balik-dampak-pandemi-covid-19

Kumar, K. S., \& Bhowmik, D. (2010). Medicinal uses and health benefits of Honey: An overview. J Chem Pharm Res, 2(1), 385-395.

Noveria, M \& Romdiati, H. (2020). Susah Mudik, Susah Balik: Dampak Pandemi Covid 19. https:// kependudukan. lipi.go.id/id/berita/ 53-mencatat covid1 9/962-sudah-mudik-susah-balik-dampakpandemi-covid-19.Akses 29 September 18.00 Wib.

Proverawati, Atikah; Rahmawati, E. (2020). Perilaku Hidup Bersih dan Sehat (PHBS). Jurnal Keperawatan Komunitas, O1(01), 40-47. https://doi.org/978-602-202-076-9

Soebyakto, B. (2011). Mudik Lebaran: Studi Kualitatif. Jurnal Ekonomi Pembangunan, 9(2), 62-67. https:// doi.org/10.29259/jep.v9i2.5001

Sulaeman, S., \& Supriadi, S. (2020). Peningkatan Pengetahuan Masyarakat Desa Jelantik Dalam Menghadapi Pandemi Corona Virus Diseases-19 (Covid-19). Jurnal Pengabdian UNDIKMA, 1(1), 12-17. https://doi.org/ 10.3 3394/jpu.v1i1.2548

Sumartono, \& Astuti, H. (2018). Penggunaan poster sebagai media komunikasi kesehatan. Jurnal Komunikologi, 15(1), 8-14.

WHO. (2020). Anjuran mengenai penggunaan masker dalam konteks COVID-19. World Health Organization, April, 1-17.

Zukmadini, A. Y., Karyadi, B., \& Kasrina. (2020). Edukasi Perilaku Hidup Bersih dan Sehat ( PHBS ) dalam. Jurnal Pengabdian Magister Pendidikan IPA, 3(1). https://doi.org/ 10.29303/jpmpi.v3i1.440 